UDC 159.922.7-053.4:615.851

DOI: $10.52534 / \mathrm{msu}-$ pp.7(2).2021.79-85

\author{
Maria I. Zamelyuk ${ }^{{ }^{\star}}$, Liudmyla I. Mahdysiuk ${ }^{2}$ \\ ${ }^{1}$ Lutsk Pedagogical College \\ 43010, 36 Voli Ave., Lutsk, Ukraine \\ ${ }^{2}$ Lesya Ukrainka Volyn National University \\ 43025, 13 Voli Ave., Lutsk, Ukraine
}

\title{
The Mastery of Art Therapy in Working with Preschool Children
}

\author{
Article's History: \\ Received: 25.01.2021 \\ Revised: 10.03.2021 \\ Accepted: 02.04.2021
}

\section{Suggested Citation:}

Zamelyuk, M.I., \& Mahdysiuk, L.I. (2021). The mastery of art therapy in working with preschool children. Scientific Bulletin of Mukachevo State University. Series "Pedagogy and Psychology", 7(2), 79-85.
Abstract. The study presents some aspects of art therapy in working with preschool children. The purpose of the study is to analyse the features of the creative activity of art therapy: game therapy, visual language, isotherapy, mandalas, collage; to reveal the characteristic features of the intervention of art in work with preschool children. The following general scientific methods were used to achieve this goal: analysis, synthesis, comparison, and modelling. It has been found that therapy helps children process difficult emotions, explore their "self", develop greater self-awareness and selfesteem, and learn to manage their emotions and solve problems. It has been studied that the creative process can help to work with memories, events and feelings that are identical to the emotions and activity of the child. It is substantiated that art therapy effectively helps children with anxiety, depression, trauma, and grief, and it can be used to increase the child's self-esteem, communication and problem-solving skills, socialisation. The necessity of using modern methods of art therapy is confirmed. The main aspects of working with preschool children are analysed. The practical side of using art therapy as an art for preschool children, tips and exercises that will help children get into the right way of thinking to create, which are included in any artistic activity to emphasise the therapeutic elements of the process. The current approaches to the art therapy process for preschool children are described: enhances creativity, allows children to express their thoughts and feelings, encourages the integration of psychological, physical and social aspects, improves productive functions, helps children make better decisions, helps children solve their problems, improves motility. The practical significance of the work is that it can be used by students, educators, psychologists, parents for in-depth study of art therapy in working with preschool children

Keywords: nonverbal communication, creativity, game therapy, visual language, isotherapy, mandalas, collage

\section{INTRODUCTION}

Today, the problem of art-therapeutic mastery in working with preschool children occupies an important position among researchers' studies, as it is not new, but relevant. This is due to the prevalence of innovative technologies in the system of educational activities of children through art. Preschool is considered to be synthesising and therefore art therapy helps children to work creatively, reduce anxiety, stress and lighten the mood. Art therapy also provides social interaction in a safe controlled environment, helping to build empathy and other important social skills. The purpose of art therapy is to support the healing process and improve the physical, mental, and emotional wellbeing of the pre-schooler. The relevance of the study of art therapy is determined by the fact that recently in Ukraine, psychotherapy is developing rapidly and its new forms and models are being actively acquired.

In order for a child to feel the multidimensionality of socio-cultural life in all its manifestations, and to be able to fully harmonise his own personality and its development in society, art comes to help, which is both an educational 
and therapeutic parameter. In particular, art therapy, as an artistic activity, can be fun and exciting, complex and provocative, as well as stimulating, provoking reflection.

Scientific approaches to art therapy in work with preschool children are being under discussion: O. Bernatska [1] explores the means of filio-art therapy, O. Voznesenska [2] describes the features of art therapy as a method, S. Gorbova [3] reveals the importance of music therapy in preschool children, N. Olkhova [4] argues about the importance of art therapy as a means of creative self-realisation of the individual, S. Lebedeva [5] reveals the pedagogical possibilities of art therapy, R. Fedorenko [6] emphasises the importance of fairy tale therapy in psychological counselling of children and adults, O. Fediy [7] dwells in more detail on aesthetic therapy.

The studies of M. Belogurova [8], N. Galameiko [9], O. Derkach [10], E. Tararina [11], J. Ball, R. Kaur [12], Delphi Heather Lee, [13], D. Waller [14], L. Rappaport [15], A. Ikemi [15], M. Miyake [15], E. Hass [16], O. NattmanSchwartz [16], A. Altman [16] deserve attention on the specified problems. In particular, O. Voznesenskaya [17] reveals media art therapy as a means of overcoming the consequences and prevention of psychotrauma. J. Ball and R. Kaur note that children who have difficulty processing and integrating sensory information, and difficulties with daily activities, can benefit from intervention, in particular, through art therapy [12]. D. Waller shares his research on the changes that occur in the process of physical involvement of materials, through the manufacture of a significant art object, through the sublimation of feelings in images, as well as through communication with the therapist through an art object. The scientist draws attention to the purpose of art therapy as a method of promoting positive change through interaction with the therapist and art materials in a safe environment [14].

The purpose of the study is theoretical and practical substantiation of the role of art therapy in the development of preschool children. The objectives of the study are: to clarify the essence of art therapy (game therapy, visual language, isotherapy, mandalas, collage); substantiate the effectiveness of art therapy in working with preschool children with anxiety, depression, trauma, and grief, as well as to increase the child's self-esteem, communication skills, socialisation; analyse the main areas of work with preschool children and offer tips and exercises for child's proper thinking in the process of creative activity.

\section{LITERATURE REVIEW}

Considering some aspects of art therapy in working with preschool children, it should be noted that the sociological context of the study of the outlined problem is related to the analysis of psychological research in the context of forms of artistic self-expression by art. In particular, O. Voznesenska substantiates the advantages of using the methodology of art therapy as a means of psychosocial recovery [18]. The pedagogical work of the scientist contains approaches to studying the use of art-therapeutic technologies in the education and social sphere. In her other scientific work, O. Voznesenskaya [19] defines the terminological field and diagnostic possibilities of art therapy, methodological aspects of application of dance-movement therapy. Undoubtedly, the foundations of the aspirations and hopes of a modern person are based on obtaining additional energy to overcome the crisis, difficulties, or a worthy path through life's trials. This is possible given the complexity of the child's real life.

O. Derkach's research is also of interest, where art therapy is presented in colour, i.e., in the relation "colourmood". By exploring the meaning of colours in their daily lives and their effects on the mind and heart, a person can gain inner peace through the effective use of these colours in everyday active life. Thus, the author notes that holistic healing and therapy can act as a "container" for powerful emotions, and can also be a means of communication between child and adult.

In their studies, L. Rappaport, A. Ikemi, M. Miyake, E. Hass, O. Nattman-Schwartz, A. Altman, I. Hrytsiuk [20], L. Magdysyuk [20], M. Zamelyuk [20], I. Podoliak [20] and others, and in particular, J. Ball and R. Kaur covered the issue of using art (music, painting, drama, literature, etc.) to develop personality and analyse its therapeutic effect. Notably, O. Fediy's research shows that the main means of art therapy include means resulting from the types of art: fine arts (art therapy), poetry or prose (bibliotherapy), dancing (dance therapy), fairy tale (fairy tale therapy). etc.

The authors share the opinion of O. Denisova that the importance of art depends on the harmonisation of social life of the individual with the environment and society, its utilitarianism, and conflict [21]. Notably, that art is directly in the combination of nature and person in terms of rhythm, symmetry, proportion, balance, which are the basis of beauty [21]. At the same time, some scientists (M. Mushkevych [22], I. Hrytsiuk [22], V. Koshirets [22], H. Khvorost [22], T. Duchyminska [22], L. Magdysyuk [22], O. Fenina [22]) note the complexity of the relationship between adult, child and art object, as well as how this process of changing the child's views on the world and its behaviour occurs.

Exploring the pedagogical foundations of art therapy in teacher's education, S. Lebedeva identifies the components of thermal centres. The author considers art therapy as a location of therapeutic and pedagogical approaches, innovative technology of the use of art, integration of multifaceted processes of human-art interaction. Actualisation of cognitive interests in various forms of art pedagogy and the formation of motivation for further independent activity in the chosen direction encourages teachers to create and expand the range of opportunities for children by combining the potential of art, pedagogy, and psychology.

Accordingly, the analysis of the above-mentioned works of scientists suggests that the problem of art therapy in working with preschool children is relevant and needs detailed study because by creating art, children can focus on their own ideas and feelings, increase self-esteem and work on social skills.

\section{METHODOLOGY}

The research was carried out using theoretical research methods: analysis (modern approaches to art therapy as art 
in working with preschool children); synthesis (study of art therapy as a holistic system: game therapy, visual language, isotherapy, mandalas, collage); comparison (highlights the current state of the problem at the Ukrainian and world levels, analyses the latest research on the selected problem); modelling (the practical side of art therapy as art; effective tools for the development of critical thinking of the imagination in the process of the art-therapeutic process by art), which allowed to formulate their own view on the problem.

The scientific work of contemporaries who intersect with theories of psychotherapy was analysed, suggesting that changes occur in emotionally-adjusted therapeutic relationships in which people can express themselves through art, gain access and revitalise memories through sensory and embodied knowledge, gain a sense of security and release tension.

The described research methods provided not only a clear presentation of the material but also systematically presented the results of theoretical research on the factors, causes, and stages of work with children using isotherapy, which uses the process of creating images as a tool to realise what is happening in the child's soul. The analysis of the scientific literature involved the study of areas of research on the problem of art therapy in working with preschool children. The stages of the study characterise the effectiveness of art therapy as a method in working with preschool children with anxiety, depression, trauma, and grief. This study showed that art therapy is successfully used in various contexts to improve the child's self-esteem, communication skills, socialisation. The methods used made it possible to relevantly and deeply analyse the selected issues at each stage.

Additionally, the article presents graphic images that form a logical perception of the studied material with the help of visualisation.

The obtained results will serve as a perspective for the empirical study of art-therapeutic work with children. This method is a useful tool for improving a child's life, as artistic expression allows children to handle adverse events in a way that is easier for them to create than to rely solely on their verbal skills.

\section{RESULTS AND DISCUSSION Analysis of the results of art therapy research in Ukraine and abroad}

In order to deepen the study of the selected issues, attention was paid to the works of authors who studied art therapy, an analysis of art therapy practices was conducted in Ukraine and abroad. The results of this analysis are presented in Table 1.

Table 1. The practice of using art therapy in Ukraine and abroad

\begin{tabular}{l|l|l}
\multicolumn{1}{|c|}{ № } & \multicolumn{1}{|c}{ Author } & \multicolumn{1}{c}{ Scope of the study } \\
1 & V. Anisimova & Art and morality to the subject of art pedagogy \\
\hline 2 & A. Bayere & Application of art therapy to people of respectable age with certain memory impairments \\
\hline 3 & O. Bulatova & Aspects of art-pedagogical approach in education \\
\hline 4 & D. Murphy & Art therapy in work with children and adolescents who have experienced sexual violence \\
\hline 5 & N. Rogers & $\begin{array}{l}\text { While using various arts for self-medication or therapeutic purposes, people do not worry } \\
\text { about the beauty of the work, the grammatical or stylistic correctness of the text, or the } \\
\text { harmony of the song's sound; art is used to express, to facilitate }\end{array}$ \\
\hline 6 & T. Karkalas & $\begin{array}{l}\text { Art therapy provides an easier way of self-expression not only for children but also for adults. } \\
\text { The individual learns to love himself by helping others to express themselves. Art therapy is } \\
\text { not teaching something, but learning the smell of flowers and a sense of silence }\end{array}$ \\
\hline 7 & T. Branch & $\begin{array}{l}\text { Works on research on the effectiveness of art therapy methods for children with learning } \\
\text { disabilities (including autism spectrum disorders - ASD) in primary education }\end{array}$ \\
\hline 8 & S. Dobby Copeland & $\begin{array}{l}\text { The practice of art therapy in addressing issues of diversity, work with traumas } \\
\text { Conducted research on how children can learn empathy through images }\end{array}$ \\
\hline 9 & D. Karmi & Cong
\end{tabular}

Source: developed by the authors on the basis of research of L. Magdysyuk, R. Fedorenko, and M. Zamelyuk [6]

As is evident from Table 1, this phenomenon of art therapy requires detailed substantiation for the impact on the child's development and its non-verbal communication, the transmission of thoughts, feelings, or emotions without words. For those who have been abused, this is one way to "tell without talking" when they cannot or are afraid to talk about specific events or feelings; a sensory approach that helps children feel and communicate on different levels visual, tactile, kinaesthetic, etc. Creative self-expression, in particular fine art, provides useful information about the development of children, especially those under the age of 10. For example, differences in creative development may help to understand the child's emotional experiences, cognition, and sensory integration, but only to a certain extent, which is not always apparent through conversation therapy alone.

Neurobiology continues to inform mental health professionals about why specific arts-based interventions in the context of therapy may be beneficial to children. In particular, certain sensory characteristics of fine art seem to be effective in improving mood, sensory integration, and calming the body and mind, especially in children who have experienced traumatic events.

Like game therapy, art therapy provides an 
opportunity to express a metaphor through artistic expression. In fact, a child who has experienced traumatic events or suffers from emotional disorders may only find it possible to create fantasy stories. With the support and guidance of a therapist, these stories serve as a way to slowly and safely release anxious or terroristic experiences.

All creative therapies are essentially relational therapies, as they involve active sensory dynamics between the practitioner and the individual, emphasising the connection between the child and the therapist. In this sense, art therapy can be useful for restoring and transforming attachment through experiential and sensory means and can take into account those early relational states that exist before words' domination, allowing the brain to establish new, more productive patterns [4]. Any professional who effectively applies the principles of art therapy to work with children is well versed in how to establish a positive commitment, attitude, and reflexive convergence, and the latter applies to the experience when two people cooperate. Creative expression, as well as a game, adds to these positive relational experiences many others, including sensory, affective, and cognitive direction.

Thus, art therapy allows children to express what has happened to them through art, and helps to reduce stress

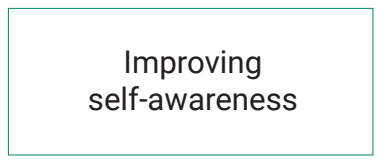

Relieving the feelings of stress, anxiety, and depression and anxiety when they work to solve these problems. At the same time, it provides children with a safe place to express their negative feelings and emotions, thus improving the mental, emotional, and physical well-being of the child.

\section{Art therapy as the mastery of a psychological tool}

Let us consider art therapy as the mastery of a psychological tool using creative materials with which children can explore their thoughts and feelings. Art therapy goes beyond colouring and includes such activities as painting; writing stories and poems; choreographic dances; writing and performing plays, which can take place both in private therapy sessions and in groups, giving children the opportunity to work on their social communication skills.

Notably, that art therapy for children can be used to help a child cope with such a life event as a serious illness, parents' divorce, fighting against low self-esteem, anxiety, depression, learning disabilities, behavioural problems, and developmental delays (autism, etc.).

Fine art offers a completely natural form of communication for most children. That is why art therapy is often considered useful to help children in various difficult situations, such as personality and emotional disorders, speech disorders, childhood trauma, grief and loss (Fig. 1).
Helping the child cope with feelings related to illness, trauma, and grief
Improving communication skills

\section{Improving $\quad$ The ability to see self-esteem problems from a different perspective}

\section{Improving \\ problem-solving skills}

Figure 1. Pedagogical bases of art therapy with children

Source: developed by the authors based on research by S. Lebedeva [5]

In the practice of art therapy, it is advisable to use such art forms as game therapy, visual language, isotherapy, mandalas, collage, to evoke the expression of the deepest feelings, to build personal stories and increase the child's self-awareness (Fig. 2).

Emotional safety: can offer children a safe way to share their story in a non-conflicting way

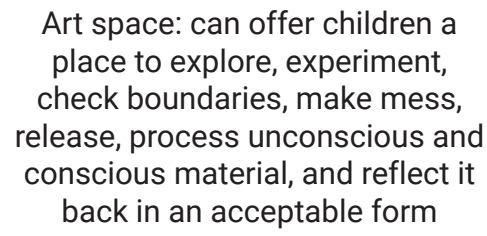

Art space: can offer children a place to explore, experiment, check boundaries, make mess, release, process unconscious and conscious material, and reflect it back in an acceptable form

Metaphor: the use of art materials is also subject to metaphor and symbolic language, and can be a very powerful way for children to express their inner feelings and sensations from the outside
The ability to externalise these feelings in a safe therapeutic space is not only playful but also in an adult way allows one to understand the unconscious world of the child, which would otherwise remain hidden
Material links: creating something material in the sessions allows one to save the experience and recall it later in the therapeutic process, if necessary

Figure 2. The main advantages of using an art-therapeutic approach with children Source: developed by the authors basing on the research by L. Magdysyuk, R. Fedorenko, and M. Zamelyuk [6]

Art therapy can include art and previous activities that allow for therapeutic physical exercise and sensory stimulation. With the help of works of art, these broad areas of concern can be addressed at the same time. For example, 
the tactile experience of art and previous activities with clay helps children with dissociative disorders to integrate the experience through the ability to "touch, create and shape objects". Art materials typically include paint, clay, pens, sand trays, drawing, pastels, oil crayons, a variety of collage materials, and a large selection of papers. Artistic creativity provides the child with a visual language in which he can express himself. For those who are trying to articulate thoughts and feelings, or are experiencing traumas for which it is almost impossible to find words, this can be an invaluable opportunity to begin to express themselves, reflect on their experiences and the problems they face. Most pre-schoolers usually express themselves more naturally and spontaneously through actions rather than words.

Thus, art provides a study of the child's world. Since the process of working with a child requires caution and delicacy, there are many reasons to use art in therapy with children: it helps to create and improve their own ideas; enriches the child's life, and helps to see new facets of the world (new or renewed view of life that charges with energy); focuses children on what worries them in order to solve the problem; is a natural way of transmitting feelings and is socially acceptable.

\section{Practical ways of using art therapy with preschool children}

It is also worth paying attention to the practical side of art therapy as a mastery for preschool children. Let us focus on exercises that will help children get into the right way of thinking, express their ideas and fantasies about the world in which they live. Children also tend to use pictures to deal with various life phenomena. These tips and exercises can be incorporated into any artistic activity to emphasise the therapeutic elements of the process (Fig. 3).

\begin{abstract}
Getting Started: children should not spend too much time thinking about what the final product will look like, and can start by choosing specific materials, colors, and textures they like. Stories, magazines, or pictures can be a good catalyst
\end{abstract}

Have conversations
Creative space: create an art space that will allow your child to experiment freely and be messy. Use a cloth or a newspaper on top of the kitchen table, in the garage, or just outside

Explore the child's creative process

Let it be: give the child time to realise his positions in the created product of art
Give them space: do not always draw with a child. When parents draw something visual while the younger child is drawing. It can be a distraction

Avoid giving instructions

Figure 3. Tips for the art-therapeutic process

Source: developed by the authors based on the research by M. Zamelyuk, L. Magdisyuk, and N. Olkhova [4]

Children's curiosity shapes their potential for creativity. It is easy for them to invent things and come up with new ideas, which is reflected in their questions and the games they invent. Through the creative process, children can learn, explore, experience new emotions and perceptions, get inspired, learn to cope with difficult situations, and improve attention, motility, and visual-spatial skills. The difference is that they express them differently. Arttherapeutic exercises help to promote self-expression and problem-solving.

The technique of "Doodle" can be used with the child using colour, creativity, and circular movements, feel relaxed: helps to get rid of anxious thoughts, exit and focus on one's emotions; stimulate one's feelings; to fantasise, to create a game idea. Exercise for drawing doodles helps to relax, develop imagination, creativity, concentration.

By asking children to draw a place where they feel safe in the exercise "Recreate a place where you feel safe", where there are waves of breath and the ocean, the child can immerse himself in the aesthetics of sensations. Children move the brushes upwards while inhaling and fill the lungs, and the hands move downwards, exhaling slowly, releasing air. Colouring the waves helps children visualise the pattern of breathing, noting that exhaling is longer than inhaling.

It is worth pointing out the main aspects of the use of dough art in working with children: the development of fine motor skills (in a simple tactile game, the dough can be compressed, rolled, flattened, cut, carved, hammered, raked, pierced, crushed); eye coordination; general concentration of attention; imagination; creativity; calming effect (playing with the dough relieves stress); scientific discoveries, etc.

Exercise "Fairy stones" helps to express negative emotions, especially anger, to materialise them with the help of dough or clay. Invite the children to gently rub the sides of the stones with their thumbs and index finger to calm them down. Children can be asked to put them in their pockets so that they can use them when faced with a situation that may cause anxiety.

Exercise "Star": establishing a relationship between child and adult. Each child is asked to draw themselves in the centre of the sheet as the sun or moon and also to "place" other members of the group in the form of stars around. In this way, the child draws those to whom he feels sympathy and trust. The information contained in the children's drawings is processed by the educator and transformed into a sociogram, which is also a drawing in which group members are drawn as geometric shapes. These figures are connected by arrows that show the nature of the relationship in the children's group.

Isotherapy, as an art-therapeutic method, is a creative, spontaneous, or thematic drawing. Mandala therapy can be offered as one of such tools in working with preschool 
children. Coloured mandalas: children can decorate or paint existing mandalas to help them feel calm and relaxed, to connect with their deepest thoughts and emotions. If the child is old enough to draw with a certain accuracy, he can make his own mandala and then decorate it. This activity not only relaxes children but also stimulates their creativity. Mandalas and attentiveness: a therapist suggests that the child pays close attention to the creative process. To do this, the therapist uses elements that contribute to an environment such as relaxing music. With the help of mandalas, children can simultaneously express their feelings and improve their creative and visual-motor skills. Moreover, the art therapist can use his work to analyse the thoughts and feelings of the child. Mandala Colouring is an art therapy exercise for children that encourages relaxation and serenity.

Notably, that art therapy contributes to a clearer, subtle expression of one's experiences, problems, internal contradictions, on the one hand, as well as creative selfexpression - on the other:

- Photos: the child can get to know himself by choosing different photos of himself and the world. The art therapist can analyse how the child chose the photos and how they relate to the child's conflicts.

- Paintings: children can use painting as their creative path. Even without realising it, the pictures show what is happening in their inner world. Moreover, an art therapist can draw with very young children to stimulate their feelings. Finger painting is a great way to stimulate different parts of the brain at the same time.

- Collages: Creating a collage can promote creativity. Moreover, it is also a great point for the child's thoughts and feelings.

- Sculpture: An art therapist may offer the child clay or the child may even make a "living sculpture" of his or her own body to express thoughts, situations, and certain feelings.

Through movement, children can integrate their emotional, cognitive, and physical bodies. It also appeals to their mood, as exercise and movement release endorphins and make it easier for them to express their emotions and ideas.

Theatre (psycho, mask image therapy) helps children to use reconstruction to express what is happening to them. Therapists often use theatre and drama to help children find solutions to their problems. The distinctness can help them think unconventionally. As an example, dance (form, rhythm, dance therapy) has incredible therapeutic power because it helps children to direct their emotions. Music (music therapy) helps to solve emotional problems, strengthens creativity and encourages socialisation, increases attention, memory and helps children to structure their language. "Music and Reflections": For this exercise, the child should find and explore their deepest thoughts with music in the background. The child and the therapist then analyse the process so that the child can integrate his or her physical, emotional, and cognitive experiences.

"Composition": For this exercise, children use their ingenuity to compose a song that reflects what they think and feel. After they compose a song, they should sing it or at least talk about it. In one part of the session, they may even rethink or rewrite the song as a symbol of conflict resolution. With the help of the song, children can express their feelings in a really fun way. For example, they can choose songs that they identify with and explore their feelings with the help of a work group or therapist.

\section{CONCLUSIONS}

The generalisation of the above-mentioned allows the authors of this study to conclude that art therapy is mastery for preschool children and has the following advantages: enhances creativity; enables children to express their thoughts and feelings, encourages the integration of psychological, physical, and social aspects, improves productive functions such as attention, memory and spatial orientation, improves speech, stimulates self-awareness, helps children work better in groups, makes children feel safe and be heard, helps to increase self-confidence, promotes good communication, helps children make better decisions, helps children cope with their problems, improves motility skills.

Art therapy is a means of improving the child's wellbeing, which allows him to learn to express himself, resolve conflicts and problems using self-expression through art. Thus, art makes it possible to build therapeutic relationships around the creative activity of the individual. Art can act as a "bridge" between two people, creating both a space and a connection between the child and the therapist. This can help reduce anxiety and allow the child to go through the process of building relationships with adults.

Further research is associated with creative counselling, which combines creativity with game therapy, art therapy, sand therapy, visual images, miniature phenomenological worlds, therapeutic games, bibliotherapy, support skills, ethics, group therapy, and many others.

\section{REFERENCES}

[1] Bernatska, O. (2010). Education of independent personality by means of filio-art therapy. Psychologist. School World, $16,3-7$.

[2] Voznesenska, O. (2015). Art therapy as a tool for psychosocial recovery of a person. Actual Problems of Sociology, Psychology, Pedagogy, 4, 28-34.

[3] Horbova, S.A. (2012). Music therapy. Experience or innovation? Lohoped, 12, 10-13.

[4] Zameliuk, M., Mahdysiuk, L., \& Olkhova, N. (2018). Art therapy as a means of creative self-realization of the individual. Psychology: Reality and Prospects, 10, 50-57.

[5] Liebiedieva, S.Yu., Ovsiannikova, Ya.O., Poliakov, I.O., \& Tytarenko, D.S. (2008). Modern problems of introduction of psychotraining technologies in the activity of the Ministry of Emergencies. Problems of Extreme and Crisis Psychology, $5,95-100$. 
[6] Mahdysiuk, L., Fedorenko, R., \& Zameliuk, M. (2019). Fairy-tale therapy in psychological counseling of children and adults. Lutsk: Vezha-Druk.

[7] Fedii, O.A. (2007). Aesthetic therapy. Kyiv: Tsentr uchbovoi literatury.

[8] Bielohurova, M. (2013). Art-therapeutic support of pre-schoolers. Preschool Psychologist. School World, 4, 1-16.

[9] Galameiko, N. (2014). Melody of the soul: Art-therapeutic club for teachers. Preschool Psychologist, 2, 18-21.

[10] Derkach, O. (2010). Art therapy to help the school. Art and Education, 2, 25-28.

[11] Tararyna, E. (2013). Art therapy workshop: Master's box. Kyiv: Эlton-2.

[12] Ball, J., \& Kaur, R. (2018). Cultural humility in art therapy and care for children and youth: Reflections on the practice of Sikh women. Journal of the Canadian Art Therapy Association, 31(1), 6-13. doi: 10.1080/08322473.2018.1454096.

[13] Lee, D.H. (2021). Pedagogy of signatures for teaching art therapy. Journal of Art Therapy of the American Art Therapy Association, 38(1), 35-44.

[14] Waller, D. (2006). Art therapy for children: How it can change. Clinical Child Psychology and Psychiatry, 11(2), $271-282$. doi: 10.1177/1359104506061419.

[15] Rappaport, L., Ikemi, A., \& Miyake, M. (2012). Focus-oriented art therapy and experiential collage: History and development in Japan. In D. Kalmanowitz, S.M. Chan, \& J. Potash (Eds.), Art therapy in Asia: To the bone or wrapped in silk (pp. 158-172). London: Jessica Kingsley.

[16] Hass, E., Nattman-Schwartz, O., \& Altman, A. (2012). The role of collective symbols as increasing resilience in children's art. Art in Psychotherapy, 39(1), 52-59. doi: 10.1016/j.aip.2011.11.005.

[17] Voznesenska, O.L. (2020). Through art therapy in search of inspiration. Psychologist. School world, 17, 3-5.

[18] Voznesenska, O. (2011). Media art therapy as a means of overcoming the consequences and prevention of psychotrauma. Kyiv: FOP Nazarenko TV.

[19] Voznesenska, O. (2008). Art-therapeutic skill: Joy and development for the whole family. Psychologist. School World, $1,24-26$.

[20] Hrytsiuk, I., Magdysyuk, L., Zamelyuk, M., \& Podoliak, I. (2021). Peculiarities of professional culture development in modern youth in Ukraine. Youth Voice Magazine, 11, 1-19.

[21] Denisova, O.V. (2008). Systemic art therapy: Theoretical substantiation of work with children. Symferopol: Tavryda.

[22] Mushkevych, M., Hrytsiuk, I., Koshirets, V., Khvorost, H., Duchyminska, T., Magdysyuk, L., \& Fenina, O. (2018). Influence of moderate physical activity on the psychophysical state of children with minimal brain dysfunctions. Journal of Physical Education and Sports, 18, 1912-1918.

\section{Марія Іванівна Замелюк ${ }^{1}$, Людмила Іванівна Магдисюк ${ }^{2}$ \\ ${ }^{1}$ КЗВО «Луцький педагогічний коледж» \\ 43010, просп. Волі, 36, м. Луцьк, Україна \\ ${ }^{2}$ Волинський національний університет імені Лесі Українки \\ 43025, просп. Волі, 13, м. Луцьк, Україна}

\section{Мистецтво арт-терапії у роботі з дітьми дошкільного віку}

Анотація. У статті представлено окремі аспекти арт-терапевтичного мистецтва у роботі з дітьми дошкільного віку. Метою дослідження $є$ аналіз особливостей мистецької діяльності арт-терапії: ігрова терапія, візуальна мова, ізотерапія, мандали, колаж; розкрити особливості втручання художнього мистецтва у роботу 3 дітьми дошкільного віку. Для вирішення вказаної мети було використано такі загальнонаукові методи: аналіз, синтез, порівняння та моделювання. З’ясовано як терапія допомагає дітям переробити важкі емоції, дослідити своє «Я», розвинути більшу самосвідомість та самооцінку та навчитися керувати своїми емоціями та вирішувати проблеми. Досліджено, що творчий процес може допомогти в обробці спогадів, подій та почуттів, які спів тотожні з емоціями та активністю дитини. Обгрунтовано, що арт-терапія ефективно допомагає дітям із занепокоєнням, депресією, травмою та горем, а також ії можна використовувати для підвищення самооцінки дитини, спілкування та навичок вирішення проблем, соціалізації. Підтверджено необхідність використання сучасних методів арт-терапевтичного мистецтва. Проаналізовано основні аспекти роботи з дітьми дошкільного віку. Запропоновано практичну сторону використання арт-терапії як мистецтва для дітей дошкільного віку, поради та вправи, які допоможуть дітям увійти в правильний спосіб мислення для створення, які включаються у будь-яку художню діяльність, щоб підкреслити терапевтичні елементи процесу. Описано актуальні підходи щодо арт-терапевтичного процесу мистецтвом для дітей дошкільного віку: підсилює творчість, дозволяє дітям висловлювати свої думки та почуття, заохочує інтеграцію психологічних, фізичних і соціальних аспектів, покращує виконавчі функції, допомагає дітям приймати кращі рішення, допомагає дітям вирішити свої проблеми, покращує моторику. Практична значущість роботи полягає в тому, що вона може бути використана студентами, вихователями, психологами, батьками для поглибленого вивчення арт-терапії у роботі з дітьми дошкільного віку

Ключові слова: невербальна комунікація, творчість, ігрова терапія, візуальна мова, ізотерапія, мандали, колаж 